\title{
Don't Get Mad, Get Persuasive!: Anger Management and Persuasion in TV Discourses
}

\author{
Antonio García Gómez \\ University of Alcalá de Henares \\ antonio.garciag@uah.es
}

\begin{abstract}
Although social scientists, journalists, and tv presenters have made great efforts to justify the relevance and importance of audience discussion programmes, these programmes have been commonly labelled as "trash television". Among the most frequent criticisms in the literature are the accusations that these programmes turn serious matters into sensationalist spectacle and indulge emotional outbursts while pretending to offer some kind of public service. The point of departure for the present paper is that a linguistic analysis of conflict talk in an institutional context may throw light on the insights offered by these programmes. More precisely, the present paper argues that conflict talk in an institutional context can build normative legitimacy by exemplifying values and moral obligations - as can be seen in the topics and guests selected for each programme. All in all, this study suggests that conflict talk is not only used as an ideological vehicle for attitude change, but that it also exerts a powerful force of social cohesion on the audience.
\end{abstract}

\section{Introduction}

Although research on conflict has been extensive in distinct fields (Hutchby, 1996a and 1996b; Myers, 2001; Wood, 2001, among others), most disciplines such as philosophy, sociology, psychology and linguistics have traditionally viewed conflict in a negative manner (Vuchinich, 2003a and 2003b). As a result, conflict has generally been undervalued (Vuchinich et al., 2002; Grimshaw, 1990) and we were urged to eradicate both at school and at home what psychologists wrongly named instances of diseased communication (García Gómez, 2007). 
Researchers seem to have ignored the fact that anger, disagreement and conflict must be seen as part of the daily fabric of life and something that is routinely negotiated in a society (Hutchby, 1996a and 1996b). For instance, anger has traditionally been contrasted with rational thought (Ellis, 2001). However, negative emotions and their expression are an integral part of routine life and serve various functions (Bodenhausen and Lichtenstein, 1987). Even at the risk of making a platitudinous large-scale social and cultural generalisation, I might get little argument if I simply asserted that incivility seemed to be on the increase. We live in a polarised culture in every sense. Television programmes show an alarming number of viperous tongues that not only gratuitously blame groups for their plight but which also seem to incite incivility in the audience. Examples of family indiscretions on talk shows (Gregori Signes, 2000 and 2001; Rama Martinez, 2003) and negative political campaigns (Willock, 1994; O'Keeffe, 2006) flood British television and demonstrate that little is sacred at the present time.

The present paper moves away from a destructive, disruptive description of conflict talk by examining the actual features of this particular type of interaction from a psychological discursive stance. In this context, I here use the term conflict talk to refer to the overt "disagreement between those interactants who see incompatible goals and potential interference in achieving these goals" (Putnan, 2001: 11). With this definition, conflict is characterised by its mixed motive nature as entailing both cooperation and competition. As Donahue (2001:21) states:

Individuals perceive that they want different things and generally impose competitive motives on others. Yet they realise that extremely contentious, coercive behaviour may not fulfil their needs efficiently. So they must communicate somewhat cooperatively.

In accordance with this quotation, I understand emotions arising from a verbal duel to be either positive or negative in their valence. In doing so, this paper contributes to this nascent literature which reacts against the little attention, or underestimation, that so complex a phenomenon has received (Grimshaw, 1990). More precisely, this study moves away from an isolated cognitive stance and focuses on issues that combine the detailed analysis of the expression of one particular emotion - anger - in talk show conflictual episodes. In particular, the analysis deals with the intersection of discursive psychology and anger; that is, how anger gets coded as an engaged discursive social activity in talk show interaction.

In this paper, I begin with introductory comments on speech act theory, followed by characterisation of my approach to the study of persuasive discourse in talk show conflict talk. From here, I move into the discursive psychological analysis of persuasion and (in-) civility and make the argument that anger expression and persuasion in public discourse must be interpreted as a combination of two key elements: discourse analysis and cognitive interpretation. Finally, I reflect on whether anger expression and persuasion in conflictual talk show interaction can solely be interpreted as an act of "incivility" or whether, on the contrary, it fulfils a public service. 


\section{A discursive psychological conceptual framework of persuasive discourse}

In contrast to the emphasis upon cognitive issues and in line with discursive psychologists (Edwards, 2000; Dickerson, 2001; García Gómez, 2009), this paper argues that persuasion is a dynamic process where discourse plays an important role. My stance, therefore, draws upon the conversation analytic emphasis on language not as a system of information but as talk-in-interaction (Sacks, 1992; Schegloff, 1995; Thornborrow, 2001a and 2001b; Rama Martínez, 2003; Lorenzo-Dus, 2005). Discursive psychologists agree that the unit of analysis can be talk-in-interaction (Potter and Wetherell, 1987). Heavily indebted to Sacks (1992), I here suggest that rather than our seeking to trace a presumed cognitive causal essence beneath persuasive discourse in talk show conflictual episodes, this particular type of discourse can be sensitively laid open. The fact that talk-in-interaction has been the neglected heart of Social Psychology has been the origin of different studies which challenge the crude mechanistic foundations of Social Psychology (Edwards and Potter, 1992; Potter, 1997; Dickerson, 1999). In this line of thought, García Gómez (2007) demonstrates that guests exploit different positive and negative politeness strategies in order to build up different social identities which can clearly show intricate orientation to the particulars of the conversational context.

The perspective adopted leads to the claim that this orientation is not surface veneer beneath which the real individual-cognitive business of persuasion takes place but, rather, it is the overt business of defending self-face behaviour as well as attacking the other's face behaviour (Donahue, 2001). In Shotter's words (1993: 17), "we must cease thinking of the 'reality' within which we live as homogenous, as everywhere the same for everyone. Different people in different positions at different moments will live in different realities".

Discursive Psychology derives its conceptual framework from ethnomethodology and conversation analysis and, therefore, it has its cornerstone in the pragmatical theory of speech acts (Donahue, 2001). I here assume that the reader is familiarised with Speech Act Theory. In brief, Austin's theory (1962) attempts to do justice to the fact that although utterances are information-conveying units, social beings convey more than their words encode. Even though speech act theory has mainly concentrated on isolated utterances, especially those made in spontaneous conversations and institutional settings (Gregori-Signes, 2000; Martínez Rama, 2003), speech acts should be understood as a broader concept which concerns different types of language use (Alston, 2000).

In line with van Eemeren and Grootendorst's (1984 and 1992) and Antaki's (1994) theory of speech acts in argumentative discourse, this study approaches television persuasive discourse and anger expression as an interactive concept rather than as a personal characteristic. In Antaki's (1994: 164) words we have "the rhetorical truism that an argument happens in an argumentative discussion - that it is an exchange of views over a difference of opinion; that the arguer means to defend a standpoint and the audience to attack it; and that they both want to resolve the dispute". What is at stake here is an understanding of treating "persuading" as a linguistic unit and weaving persuasion and anger expression into the fabric of speech acts. Finally, detailed inspection of the data confirms Antaki's claim that arguing is the illocutionary act (Antaki, 1994: 166) - the communicative side of a verbal dispute - and persuading is the perlocutionary outcome." In this sense, the perlocution of conflicting is the 
sum of all the felicity conditions of argument being met.

\section{Data collection and participants}

The sample of data is based on the video-tape recording and transcription of one of the most popular talk shows on British Television: Kilroy. The total number of programmes is fifteen and together they add up to around 180,000 words. For the sake of space, the total number of extracts used to illustrate the different persuasive strategies is four. Kilroy is quite an openformat show. Contrary to most talk shows, Kilroy does not have a strict agenda that has to be followed step by step. Once the topic is introduced by the presenter and some guests are asked directly to make comments on their own experiences, long stretches of the programme interaction are developed by the guests' free contributions to discourse. In short, the basic structure is not that of presenter's questions and guests' answers, but rather it is common to establish a free dialogue among all the guests. With regard to representing the talk in written form, I have chosen to transcribe the conversations in a way that is not only faithful to the spontaneity and informality of the talk, but is also accessible to readers who are not familiar with conversational literature or phonological / prosodic symbols.

The final corpus contained 89,937 annotated utterances from fifteen programmes that were highly confrontational. Following García Gómez' (2007 and 2009) conversational analysis of talk show conflict talk, every utterance has been coded for its pragmatic meaning.

\begin{tabular}{|l|r|l|}
\hline Taxonomy of Speech Acts in conflictual episodes & Instances & Percentage \\
\hline Elicit: asking for information & 12,943 & $14.3911 \%$ \\
\hline Elicit: commitment to a future course of action & 7,539 & $8.3825 \%$ \\
\hline Elicit: agreement with own point of view & 1,297 & $1.4421 \%$ \\
\hline Elicit: clarification of opponents' point of view & 5,274 & $5.8663 \%$ \\
\hline Elicit: confirmation of opponent's point of view & 3,992 & $4.4386 \%$ \\
\hline $\begin{array}{l}\text { Elicit: commitment to course of action due to agreement with } \\
\text { speaker's point of view }\end{array}$ & 3.267 & $3.6325 \%$ \\
\hline Directive: imposition of a course of action on the opponent & 5,498 & $6.1131 \%$ \\
\hline Directive: suggestion of a course of action for the opponents' benefit & 6,569 & $7.3040 \%$ \\
\hline Directive: threat directed to the opponent & 9,246 & $10.2805 \%$ \\
\hline Directive: warning directed to the opponent & 5,398 & $6.0019 \%$ \\
\hline Informative: direct positive self-evaluation & 2,576 & $2.8642 \%$ \\
\hline Informative: indirect positive self-evaluation & 4,586 & $5.0991 \%$ \\
\hline Informative: direct negative self-evaluation & 1,395 & $1.5510 \%$ \\
\hline Informative: indirect negative self-evaluation & 1,004 & $1.1163 \%$ \\
\hline Informative: direct positive evaluation of the opponent & 2,678 & $2.9776 \%$ \\
\hline Informative: indirect positive evaluation of the opponent & 1,837 & $2.0425 \%$ \\
\hline Informative: direct negative evaluation of the opponent & 12,295 & $13.6706 \%$ \\
\hline Informative: indirect negative evaluation of the opponent & 3,569 & $3.9683 \%$ \\
\hline Total & 89,937 & $100 \%$ \\
\hline
\end{tabular}

Table 1. Taxonomy of speech acts found in the corpus and the frequency of each pragmatic meaning of utterances. 


\section{Self-construal, facework, and conflict styles in TV persuasive discourse}

The persuasion complex itself, at the centre of the interaction, is made up of elicitations, directives and informatives of various kinds. In addition, most of these turns are produced by self-selection and present a high degree of overlapping and interruption, due to the fact that each participant is likely to take any opportunity to express their own ideas; that is, each has strong reasons to be in the speaker's role.

In television persuasive discourse, the negotiation of two opposing points of view is embedded in a complex social interaction of face work acts (Pérez de Ayala, 2001; LorenzoDus, 2005). The present paper analyses the exploitation of politeness strategies involved in elicitations, directives and informatives in television conflict talk, and takes a step further by combining a pragmatic stance with a psychological discursive analysis of speech acts. This in turn will throw further light on how language plays a major role in constructing the participants' social identities. What is suggested here is that the particular persuasive strategies behind television conflict talk can build normative legitimacy by exemplifying values and moral obligations. Furthermore, this study suggests that conflict talk is not only used as an ideological vehicle for attitude change, but that it also exerts a powerful force of social cohesion on the audience.

As discussed in earlier work (García Gómez, 2007), persuasive discourse is concerned with identity message behaviour; that is, with the individual's sensitivity toward the other's and self's reputation, or with projected images that each party wishes to have validated in the social interaction with the other (Rogan and Hammer, 1994; Hammer, 2001). Close inspection of the data has revealed that persuasive discourse and identity message behaviour in talk show conflict talk can be usefully classified into three types of face work act - two of which cluster around self-face behaviours and one of which centres on both self-face and other-face behaviours.

\subsection{Persuasive discourse in TV interaction: Defending self-face behaviours}

These behaviours are self-focused messages that are face honouring in nature and guard against possible future attack messages from the other party. Although there are instances of directives, this persuasive strategy is mainly realised by means of elicitations and informatives. They are polemical expressions based on fear, anxiety and anger which reflect how the speaker attempts to attract the notice of the presenter and the audience in order to convince the opponent. The strategy is polemical in so far as it involves a complex reaction pattern involving experiential, behavioural, and physiological elements, by which the individual attempts to deal with a personally significant matter or event (Arbib and Fellous, 2004: 15). Furthermore, there is a fine line between persuasion and anger expression in the development of these particular conflictual episodes. Table 2 shows the distribution of speech acts in this persuasive strategy. 


\begin{tabular}{|l|l|l|l|}
\hline Distribution of speech acts in corpus & Ratio & $\begin{array}{l}\text { Distribution of speech acts in } \\
\text { corpus }\end{array}$ & Ratio \\
\hline Elicit (1): asking for information & 9.2 & $\begin{array}{l}\text { Directive(10): warning directed to } \\
\text { the opponent }\end{array}$ & 1.2 \\
\hline $\begin{array}{l}\text { Elicit (2): commitment to a future course } \\
\text { of action }\end{array}$ & 6.9 & $\begin{array}{l}\text { Informative (11): direct positive } \\
\text { self-evaluation }\end{array}$ & 2.7 \\
\hline $\begin{array}{l}\text { Elicit (3): agreement with own point of } \\
\text { view }\end{array}$ & 9.1 & $\begin{array}{l}\text { Informative (12): indirect positive } \\
\text { self-evaluation }\end{array}$ & 14.6 \\
\hline $\begin{array}{l}\text { Elicit (4): clarification of opponents' } \\
\text { point of view }\end{array}$ & 3.5 & $\begin{array}{l}\text { Informative (13): direct negative } \\
\text { self-evaluation }\end{array}$ & 1.3 \\
\hline $\begin{array}{l}\text { Elicit (5): confirmation of opponent's } \\
\text { point of view }\end{array}$ & 6.8 & $\begin{array}{l}\text { Informative (14): indirect negative } \\
\text { self-evaluation }\end{array}$ & 0.7 \\
\hline $\begin{array}{l}\text { Elicit (6): commitment to course of action } \\
\text { due to agreement with speaker's point of } \\
\text { view }\end{array}$ & 6.2 & $\begin{array}{l}\text { Informative (15): direct positive } \\
\text { evaluation of the opponent }\end{array}$ & 5.2 \\
\hline $\begin{array}{l}\text { Directive (7): imposition of a course of } \\
\text { action on the opponent }\end{array}$ & 0.2 & $\begin{array}{l}\text { Informative (16): indirect positive } \\
\text { evaluation of the opponent }\end{array}$ & 2.4 \\
\hline $\begin{array}{l}\text { Directive (8): suggestion of a course of } \\
\text { action for the opponents' benefit }\end{array}$ & 0.9 & $\begin{array}{l}\text { Informative (17): direct negative } \\
\text { evaluation of the opponent }\end{array}$ & 17.1 \\
\hline $\begin{array}{l}\text { Directive (9): threat directed to the } \\
\text { opponent }\end{array}$ & 0.3 & $\begin{array}{l}\text { Informative (18): indirect negative } \\
\text { evaluation of the opponent }\end{array}$ & 11.7 \\
\hline & & Total & 100 \\
\hline
\end{tabular}

Table 2. Distribution of Speech Acts in Defending Self-face Behaviours.

First, as a glimpse of the kinds of phenomena under analysis, consider these utterances from an episode of Kilroy, in which Woman 14 and Woman 15 talk about Man 1. It is snippet from M1's story about the events leading up to his break-up and the beginning of a new loving relationship:

\section{Extract 1: Left after a long marriage}

\begin{tabular}{|c|c|c|}
\hline 170 & W14 & $\begin{array}{l}\text { let me say (.) it's NOT RIGHT to carry on with the other person but (.) at the same time (.) it seems } \\
\text { to me the time you have had abroad (.) you had very little contact with the wife at home (.) to know } \\
\text { what was going on and (.) you know (.) if you still felt something for her (.) I am sorry= }\end{array}$ \\
\hline 171 & W15 & $\begin{array}{l}=\mathrm{I} \text { 'm sorry for you (.) I'm sorry (.) you should have worked at your marriage and sort it out (.) tried } \\
\text { to find out what's gone wrong (.) you should have communicated (.) more (.) erm (.) rekindled her } \\
\text { love in some way }\end{array}$ \\
\hline 172 & M1 & $\begin{array}{l}\text { I loved her to pieces but there was NO WAY I could sort it ] out (.) I fell in love with somebody else } \\
\text { (.) I couldn't help it (.) I am just responsible for my feelings (.) there was nothing I could do (.) I fell } \\
\text { in love }\end{array}$ \\
\hline 173 & W15 & ]you should have divorced her then (.) I'm sorry but that's the way I think= \\
\hline 174 & M1 & $=$ it's better for the children to have two parents (.) right] \\
\hline 175 & W15 & ]two parents that are not arguing (.) I don't think this is helpful to the child] you should \\
\hline 176 & M1 & ]that's easier] \\
\hline 177 & W15 & $\begin{array}{l}\text { Jyou were selfish (.) you just satisfied your most basic instincts (.) you should have divorced her (.) } \\
\text { you should have been straightforward (.) that's what she has done to you if she had fallen in love with } \\
\text { another man }\end{array}$ \\
\hline
\end{tabular}


If we accept language as a social construct, we must also accept the existence of such generic activity as indicative of some social cohesiveness or collectivity (O'Keeffe 2006: 27). In the extract above, W14 and W15 provide, as part of their narrative, a time and place for, and specification of, M1's emotions when they hear about his affair with another woman when he was still married. Both female guests are sorry for him but the presence of modal verb "Should + socially acceptable action" characterises M1's reaction as irrational and emotional.

Both M1 and W15 describe the same event - the fact of being with another person when you are still married - as an emotional behaviour. On the one hand, M1 describes this emotional behaviour as a passive reaction, and denies his agency in this socially inacceptable behaviour (Turn 172: "I fell in love with somebody else (.) I couldn't help it (.) I am just responsible for my feelings (.) there was nothing I could do (.) I fell in love"). This fails to convince W15 as she perceives the same event as a controllable action where M1 had an emotional reaction and did not control it as he should have done "Turn 177: you were selfish (.) you just satisfied your most basic instincts (.) you should have divorced her (.) you should have been straightforward (.) that's what she has done to you if she had fallen in love with another man"). The strategy is likely to fail as it is based on the dichotomy between how someone felt and what he or she did about it; on the notion of controlling one's passion, physical violence, etc. Furthermore, the failure is emphasised by the fact that the same reality is negotiated from two irreconciliable points of view: natural action versus moral action (Donahue, 2001). As seen in the example above, M1 conceptualises an unfaithful relationship as unconscious whereas W15 depicts the same situation as a moral issue which encapsulates a negative social judgement.

In brief, communication in this relational condition includes factual information (confessing an infidelity or a drinking problem), sharing (speaking about private issues), attempts at bolstering one's own position and credibility (giving proper reasons for what one did), and messages about termination and withdrawal (inability to convince the other).

\subsection{Persuasive discourse in TV interaction: Attacking and restoring self-face behaviours}

Attack self-face behaviours are statements against one's self-image. Interestingly enough, most of the conflictive situations in the data were the result of personal threats to interactants' own social identity (Edwards and Potter, 1992; Edwards, 2001). Linguistically speaking, this strategy shows a disposition toward negotiating two opposing realities. Due to this process of negotiation, guests mainly rely on informatives that express varying degrees of adhesion to their own point of view (García Gómez, 2000). The presence of directives and informatives can be related to ways of expressing the speaker's emotions which cover a range extending from fear of social criticism to aggression.

Inspection of the corpus shows that the kernel of this strategy lies in the fact that the speaker's reasoning searches for a power balance between the interactants. Needless to say, this strategy underlines the hypothesis that there is a fine line between persuasion and anger expression, as the negotiation of opposing realities between speakers depends on whether guests are able to express rationally their reasoning of a particular disputed issue statement (Cotterill, 2003). The experiencing of anger - as a result of audience social pressure - 
prevents guests from rationally articulating their point of view and contributes to the blurring between persuasion and anger expression (Joseph, 2004). Table 3 shows the distribution of speech acts in this persuasive strategy.

\begin{tabular}{|l|l|l|l|}
\hline Distribution of speech acts in corpus & Ratio & $\begin{array}{l}\text { Distribution of speech acts } \\
\text { in corpus }\end{array}$ & Ratio \\
\hline Elicit (1): asking for information & 37 & $\begin{array}{l}\text { Directive(10): warning } \\
\text { directed to the opponent }\end{array}$ & 9 \\
\hline $\begin{array}{l}\text { Elicit (2): commitment to a future } \\
\text { course of action }\end{array}$ & 5 & $\begin{array}{l}\text { Informative (11): direct } \\
\text { positive self-evaluation }\end{array}$ & 104 \\
\hline $\begin{array}{l}\text { Elicit (3): agreement with own point of } \\
\text { view }\end{array}$ & 58 & $\begin{array}{l}\text { Informative (12): indirect } \\
\text { positive self-evaluation }\end{array}$ & 176 \\
\hline $\begin{array}{l}\text { Elicit (4): clarification of opponents' } \\
\text { point of view }\end{array}$ & 48 & $\begin{array}{l}\text { Informative (13): direct } \\
\text { negative self-evaluation }\end{array}$ & 119 \\
\hline $\begin{array}{l}\text { Elicit (5): confirmation of opponent's } \\
\text { point of view }\end{array}$ & 43 & $\begin{array}{l}\text { Informative (14): indirect } \\
\text { negative self-evaluation }\end{array}$ & 72 \\
\hline $\begin{array}{l}\text { Elicit (6): commitment to course of } \\
\text { action due to agreement with speaker's } \\
\text { point of view }\end{array}$ & 23 & $\begin{array}{l}\text { Informative (15): direct } \\
\text { positive evaluation of the } \\
\text { opponent }\end{array}$ & 44 \\
\hline $\begin{array}{l}\text { Directive (7): imposition of a course of } \\
\text { action on the opponent }\end{array}$ & $\begin{array}{l}\text { Informative (16): indirect } \\
\text { positive evaluation of the } \\
\text { opponent }\end{array}$ & 36 \\
\hline $\begin{array}{l}\text { Directive (8): suggestion of a course of } \\
\text { action for the opponents' benefit }\end{array}$ & 47 & $\begin{array}{l}\text { Informative (17): direct } \\
\text { negative evaluation of the } \\
\text { opponent }\end{array}$ & 129 \\
\hline $\begin{array}{l}\text { Directive (9): threat directed to the } \\
\text { opponent }\end{array}$ & 16 & $\begin{array}{l}\text { Informative (18): indirect } \\
\text { negative evaluation of the } \\
\text { opponent }\end{array}$ & 47 \\
\hline Total & 100 \\
\hline
\end{tabular}

Table 3. Distribution of Speech Acts in Attacking and restoring self-face behaviours.

In extract 2, a couple responds in turn to the presenter's invitation to provide some historical background to W2's drinking problem. W2 starts by expressing her shame of what she has become because of her drinking problem (Turn 68: "I'm ashamed of what I am"). As the extract shows, guests seem to have a motive to evaluate their own social category membership negatively. This is achieved through social comparison between ingroup (negative evaluation) and outgroup (positive evaluation). In evaluating their own ingroup negatively, interactants attempt to exit from the group and guarantee their acceptance in the outgroup - the one that is socially accepted amd positively evaluated (Hogg and Vaughan, 1995).

\section{Extract 2: Standing by an alcoholic partner}

\begin{tabular}{|c|c|c|}
\hline 67 & $\mathrm{~K}$ & what do you feel about your kids $\uparrow$ \\
\hline 68 & W2 & I love them too (.) I'm ashamed of what I am $=$ \\
\hline 69 & $\mathrm{~K}$ & $=$ okay $($.$) what do you think you are doing to the kids \uparrow$ what should we do about it? \\
\hline 70 & W2 & $\begin{array}{l}\text { well (2.7) ((sights)) they both love me(.) they keep telling me they love me (.) they don't want } \\
\text { us to split up }\end{array}$ \\
\hline 71 & $\mathrm{~K}$ & then you know when they say that (.) they are telling the truth $=$ \\
\hline
\end{tabular}




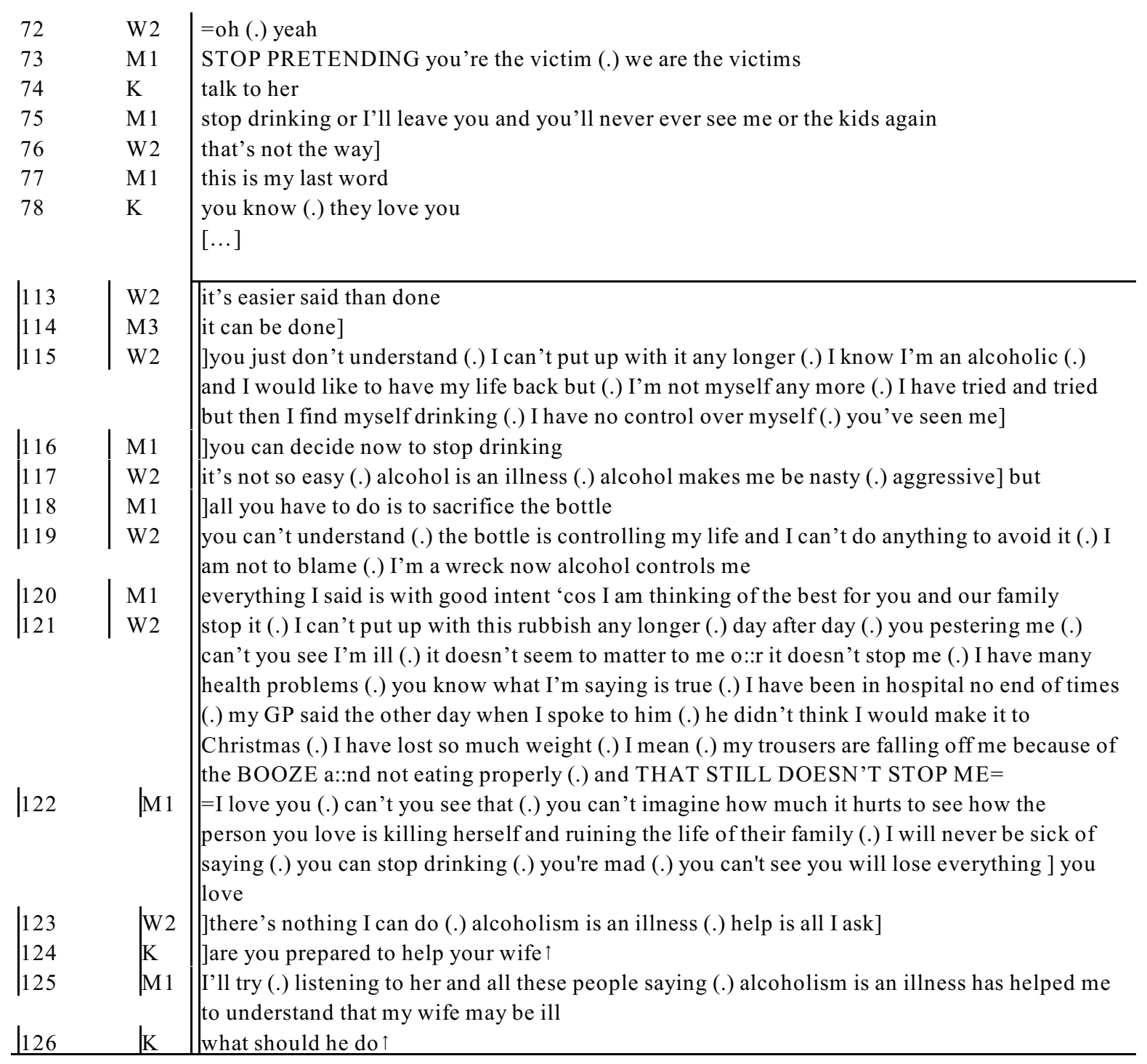

Extract 2 is an example of inclusive alignment within the participation framework. The guests are aligned with the presenter and each other. Then the presenter, using the pronoun 'we' (Turn 69: "what should we do about it?") pivots his alignment to include the studio and non-studio audience and, following applause, he re-aligns so as to address all of the audience directly. W2's depiction of her drinking problem interspersed with routine and unremarkable arguments is found alongside with her husband's (M1) alternative account.

On the one hand, the attention that both participants give to the effect of heavy drinking upon their marriage is part of their factual accounting (Vuchinich, 2003a); these are offered as long-term observations, covering many individual events, and provide the basis for a generalised characterisation of the relationship itself(Antaki, 1994). Note the specific contrast with what W2 characterises as routine arguments (Turn 121: "stop it (.) I can't put up with this rubbish any longer (.) day after day (.) you pestering me (.) can't you see I'm ill (.) it doesn't seem to matter to me o::r it doesn't stop me [...]". M1 also works up their repeated nature, but 
not as a means of normalising them (Turn 122: "I love you (.) can't you see that (.) you can't imagine how much it hurts to see how the person you love is killing herself and ruining the life of their family (.) I will never be sick of saying (.) you can stop] drinking"). In this way, M1 produces a pathologising, rather than normalising depiction of the event (Turn 122: "you're mad (.) you can't see you will lose everything you love").

Not only are these different and inconsistent accounts, but also the recurrent communication failures, augmented by profound distrust and lack of understanding, ultimately fuel the entire conflict (Turn 115: “you just don't understand"; Turn 119: "you can't understand; Turn 121: “can't you see I'm ill”). Let us discuss these aspects in detail. The attacking self-face behaviour strategy is based on contrasting accounts constructed precisely in relation to an actual alternative, in that they display an awareness of that alternative. M1, on the one hand, accuses his wife of pretending (Turn 73: "Stop pretending you're the victim (.) we are the victim") and presents his wife's drinking problem as the origin of all their family problems and the cause of his decision to divorce her (Turn 118: "all you have to do is to sacrifice the bottle" and Turn 120: "everything I said is with good intent "cos I am thinking of the best for you and our family").

On the other hand, W2 depicts her drinking as an illness which deprives her of will (Turn 115: "I'm not myself anymore [...] I have no control over myself"; Turn 117: "alcohol is an illness (.) alcohol makes me be nasty (.) aggressive [...]"). In doing so, she presents herself as a victim and a puppet in the hands of alcohol (Turn: 119: "I'm not to blame (.) I am a wreck now alcohol controls me"). W2 attacks her self-face behaviours but denies agency in the actions. This is her way of avoiding responsibility for being alcoholic and being aggressive. The desire is to withdraw from the previously defined roles and create new role frameworks to guide the relationship (Hogg and Vaughan 1995). It is the intervention of the presenter that stops the negotiation of realities as he asks another guest to suggest what should be done to change this situation. This guest starts narrating his own story and the episode is interrupted. Evidence from the corpus suggests that this persuasive strategy reflects a complex mental process and a subtle approach. As most of the conflictive situations were the result of personal threats to interactants' social identity, participants commonly attack self-face behaviours as a way to pave the way and create solidarity with the opponent (García Gómez, 2007). Guests are unable to evaluate their social category membership positively (i.e. being an unfaithful husband; having problems with alcohol, etc.) and, therefore, the relative status of inferiority of the group constitutes a threat to the social identity of the individual group member (Hogg and Vaughan, 1995). In these cases, if the presenter does not stop the conflictive episode, participants supplement the persuasive strategy of attacking their own self-face behaviours by exiting from this negatively evaluated group. In my own terms, these participants attempt to restore their own self image by anticipating a counterargument to a potential face attack message from the opponents. As Ellemers (1993) points out, whether an individual selects one strategy or other depends in large parts on his or her beliefs regarding social mobility and social change (Augoustinos and Walker, 1995).

In Conflict Talk, social mobility refers to the belief that the group boundaries are open rather than closed, that it is possible to leave one group and join another. Following Foucault (1972), there is no doubt that when any participant speaks, this person is taking up a pre- 
existent subject position that is subjected to the regulatory power of that discourse (Barker and Galasiriski, 2001). In order to exit from the group, the speaker addresses all the negative characteristics of the ingroup trying to block the opponent as part of his or her past and attaches all the positive characteristics of the opponent's in-group to his or her present situation. This present-past dichotomy aims to prove the guest has changed and cannot be condemned because of a mistake he or she made in his or her past.

In extract 3, M1 combines this two-fold persuasive strategy as he initially attacks his own self-face behaviour and then tries to restore his own face:

\section{Extract 3: My inlaws don't like me}

\begin{tabular}{|c|c|c|}
\hline 82 & $\mathrm{~K}$ & $=$ you really love her $($.$) don't you \uparrow$ \\
\hline 83 & M1 & I do (.) yeah \\
\hline 84 & $\mathrm{~K}$ & $\begin{array}{l}\text { I can tell when she was speaking and you were looking at her (.) what are your feelings when she was } \\
\text { talking } \uparrow\end{array}$ \\
\hline 85 & M1 & $\begin{array}{l}\text { I'm gutted (.) I'm gutted (.) as I said (.) I haven't come on here to blame her] I am not proud of what I } \\
\text { did (.) I have made many mistakes (.) you know (.) but as I said] }\end{array}$ \\
\hline 86 & $\mathrm{~K}$ & ]talk to her \\
\hline 87 & M1 & $\begin{array}{l}\text { I haven't come on here to blame you (.) I know you love rachel to pieces (.) you're a good mother (.) } \\
\text { but you are a bit overprotective (.) I would like to have had one more chance with rachel without so } \\
\text { much interfering (.) we two want rachel to be happy (.) don't we }{ }^{\dagger}\end{array}$ \\
\hline 88 & W2 & $\begin{array}{l}\text { you said that before (.) you had plenty of opportunities (.) I love my daughter (.) you love rachel (.) ok } \\
\text { (.) in a different way (.) I'm here to protect rachel (.) she's all I've got (.) at the end of the day (.) if I don't } \\
\text { think you're the right person for her (.) I'm going to say it (.) I'm going to say it (.) well] }\end{array}$ \\
\hline 89 & M1 & $\begin{array}{l}\text { JI'm the right person (.) margaret (.) I love your daughter to pieces (.) I'm sorry (.)I know I made } \\
\text { mistakes (.) I know I have fallen out no end of times (.) I know I have come back and said I HAVE } \\
\text { CHANGED (.) but now I have (.) I have CHANGED (.) I know I was a bit of a boozer (.) I used to } \\
\text { hang out with lads but ] I've changed }\end{array}$ \\
\hline 90 & W2 & $\begin{array}{l}\text { ]that's what I want to point out (.) I don't want her to go through life (.) without anything and YOU } \\
\text { spending the money on booze (.) not buying anything for her }\end{array}$ \\
\hline 91 & M1 & $\begin{array}{l}\text { you know I've changed (.) a::nd (.) erm (.) I didn't spend all the money on booze (.) you're } \\
\text { exaggerating= }\end{array}$ \\
\hline 92 & W2 & $=\operatorname{I'm} \operatorname{NOT}($.$) andy$ \\
\hline 93 & M1 & I didn't spend all the money on drinking \\
\hline 94 & W2 & you know you did \\
\hline 95 & M1 & $\begin{array}{l}\text { just let me show you I've changed (.) I had a drinking problem (.) I spent our money (.) you're right (.) } \\
\text { but that's over (.) now I know who I am and who I want to be with (.) just let me] }\end{array}$ \\
\hline 96 & W2 & ]I don't] \\
\hline 97 & M1 & $\begin{array}{l}\text { JI know you only want to protect your daughter (.) but I love her to pieces (.) just trust me (.) now I am } \\
\text { proud of the man I am (.) I've changed (.) people change (1.3) all I want is another chance (.) I am not } \\
\text { better than anybody else but I am not the man you're saying (.) erm (.) only lord knows how much I have } \\
\text { suffered (.) I'm sorry for what I did (.) I cried my eyes out (.) nobody is an angel (.) now I only want } \\
\text { another chance (.) please] ((crying)) }\end{array}$ \\
\hline 98 & W5 & ]stop interfering ((to Margaret)) ((applause)) \\
\hline 99 & W2 & oh well (.) I must accept people may change (.) we all deserve a second chance in life (.) I will step back \\
\hline
\end{tabular}

The statistical analysis of speech acts reflects that this persuasive strategy is mainly realised by means of informative moves that aim at establishing three main facts that support the success of the strategy: 
(a) Claiming common ground. M1 clearly builds up his discourse exploiting positive politeness strategies (Brown and Levinson, 1987) as he claims common ground by attending to W2's wants and exaggerating approval and sympathy with his mother-in-law (Turn 87: "I haven't come on here to blame you (.) I know you love rachel to pieces (.) you're a good mother"). This positive politeness strategy precedes M1's complaint: W2 is interfering. Notice how he also exploits a negative politeness strategy aimed at minimising W2's positive and negative face threat. On the one hand, M1 grades the negative adjective (Turn 87: "but you are a bit overprotective") and, on the other, he avoids coercing W2 (Turn 87: "I haven't come on here to blame you").

(b) Negative depiction of past actions. Because of his drinking problems, M1 finds himself in a group which cannot be evaluated positively in relation to other groups (i.e. responsible partners that are aware of their rights and duties). The success of the strategy lies in the fact of relating all these negative actions to a past mistake that has nothing to do with the person he is at the present time. First, M1 avoids disagreement and conveys that speaker and opponent are cooperators as both of them love Rachel (Turn 89: "I'm the right person (.) margaret (.) I love your daughter to pieces"). Second, there is a personal-centre switch as M1 narrates all the mistakes he made in the past as if he were W2. Notice the repetitive use of the structure "I know" that precedes all the negative cricitism, clearly presupposing W2's values are the same as M1's values at present. This presupposition manipulation aims at claiming common ground and seeking agreement with the opponent and can also be interpreted as an attempt to prove he really has changed (Turn 89: "I know I made mistakes (.) I know I have fallen out no end of times (.) I know I have come back and said I HAVE CHANGED (.) but now I have (.) I have CHANGED (.) I know I was a bit of a boozer (.) I used to hang out with lads but ] I've changed").

(c) Presentation of the new values that describe the speaker as belonging to a new and socially acceptable in-group. At an individual level, M1 shows he has a positive selfesteem through an attempt to promote a positive atmosphere where others think well of him (Turn 97: "now I am proud of the man I am"). As Augoustinos and Walker (1995: 110) point out, an evaluation of one's self on both the personal and social levels will lead to an explicit social comparison with other social categories (Turn 97: "I am not better than anybody else but I am not the man you're saying"). By describing all his suffering, M1 purports to exit from the in-group that is negatively evaluated. The persuasive strategy consists of two defining qualities, as explained in what follows. W2 is made to feel guilty and is put in a situation where forgiving is the appropriate social thing to do (Turn 97: "I love her to pieces (.) just trust me (.) I've changed (.) people change (1.3) all I want is another chance (.) only lord knows how much I have suffered (.) I'm sorry for what I did (.) I cried my eyes out (.) nobody is an angel (.) now I only want another chance (.) please"). The effectiveness of the persuasive strategy lies, on the one hand, in the social pressure deriving from the situational context - TV interaction. On the other, the effectiveness has to do with the ability of M1 to put W2 in a corner and she eventually accepts the validity of M1's membership in the group as someone who made a mistake at some point of their life but now has changed (Turn 99: "oh well (.) I must accept people may change (.) we all deserve a second chance in life (.) I will step back"). 
4.3. Persuasive discourse in TV interaction: Defending self face behaviours and attacking other's face behaviours

This persuasive strategy refers to the speakers' direct challenges to the opponent and the outgroup he or she represents. Contrary to the previous strategy, the speaker accepts the negative consequences of whatever socially reprehensible action he or she is responsible for and, in turn, challenges the negatively valued group membership that the opponent ascribes to him or her. Despite the valuable work by Jost (1995), the psychological and social costs of internalised ingroup derogation have largely been ignored by social psychology. Augoustinos and Walker (1995: 118) point out that "this internalised ingroup derrogation aims at justifying the social system that makes it possible to produce the relative social positions of different ingroups and outgroups".

Rather than bringing about a wide consensus, guests employ a forceful approach and attempt to impose their opinion on the opponents considering that discussion of opposing points of view has proven to be ineffective. This persuasive strategy completes one of the gaps in the literature of Social Identity Theory as it deals with the consequences of having a positive self-esteem and/or of defending a positive social identity at any cost. Linguistically speaking, guests not only look for behaviour that suggests real or potential conflict but they deliberately provide no resolution. Being somewhat dictatorial in nature, this strategy is mainly realised through informatives and directives. Table 4 shows the distribution of speech acts in this persuasive strategy.

\begin{tabular}{|l|l|l|l|}
\hline Distribution of speech acts in corpus & \multicolumn{1}{|c|}{ Ratio } & Distribution of speech acts in corpus & Ratio \\
\hline Elicit (1): asking for information & 37 & $\begin{array}{l}\text { Directive(10): warning directed to the } \\
\text { opponent }\end{array}$ & 9 \\
\hline $\begin{array}{l}\text { Elicit (2): commitment to a future } \\
\text { course of action }\end{array}$ & $\begin{array}{l}\text { Informative (11): direct positive self- } \\
\text { evaluation }\end{array}$ & 104 \\
\hline $\begin{array}{l}\text { Elicit (3): agreement with own point of } \\
\text { view }\end{array}$ & 58 & $\begin{array}{l}\text { Informative (12): indirect positive self- } \\
\text { evaluation }\end{array}$ & 176 \\
\hline $\begin{array}{l}\text { Elicit (4): clarification of opponents' } \\
\text { point of view }\end{array}$ & $\begin{array}{l}\text { Informative (13): direct negative self- } \\
\text { evaluation }\end{array}$ & 119 \\
\hline $\begin{array}{l}\text { Elicit (5): confirmation of opponent's } \\
\text { point of view }\end{array}$ & $\begin{array}{l}\text { Informative (14): indirect negative self- } \\
\text { evaluation }\end{array}$ & 72 \\
\hline $\begin{array}{l}\text { Elicit (6): commitment to course of } \\
\text { action due to agreement with speaker's } \\
\text { point of view }\end{array}$ & 23 & $\begin{array}{l}\text { Informative (15): direct positive evaluation } \\
\text { of the opponent }\end{array}$ & 44 \\
\hline $\begin{array}{l}\text { Directive (7): imposition of a course of } \\
\text { action on the opponent }\end{array}$ & 7 & $\begin{array}{l}\text { Informative (16): indirect positive } \\
\text { evaluation of the opponent }\end{array}$ & 36 \\
\hline $\begin{array}{l}\text { Directive (8): suggestion of a course of } \\
\text { action for the opponents' benefit }\end{array}$ & 47 & $\begin{array}{l}\text { Informative (17): direct negative evaluation } \\
\text { of the opponent }\end{array}$ & 129 \\
\hline $\begin{array}{l}\text { Directive (9): threat directed to the } \\
\text { opponent }\end{array}$ & 16 & $\begin{array}{l}\text { Informative (18): indirect negative } \\
\text { evaluation of the opponent }\end{array}$ & 47 \\
\hline & $\begin{array}{l}\text { Total } \\
100\end{array}$ \\
\hline
\end{tabular}

Table 4: Distribution of Speech Acts in Defending self face behaviours and attacking other's face behaviours. 
In the following extract, M23 sends messages that protect his self-image from potential future attack by challenging all the social conventions which members of a particular culture may share.

\section{Extract 4: Slimming for summer}

\begin{tabular}{|c|c|c|}
\hline 182 & W22 & is it a problem for you if the woman you love is larger than you $\uparrow$ \\
\hline 183 & M23 & I've never been in love with one \\
\hline 184 & $\mathrm{~W} 22$ & would you feel attracted by one $\uparrow$ \\
\hline 185 & M23 & I don't think so \\
\hline 186 & W22 & be sincere (.) would you mind being seen in public with a large lady $\uparrow$ \\
\hline 187 & M23 & yeah $(2.3.) \mathrm{I}]$ \\
\hline 188 & W22 & $\begin{array}{l}\text { JI wouldn't diet for a man like you (.) you can't judge a book by its cover (.) I'm fat but I am a } \\
\text { human being (.) people should take me for my personality and what I'm like inside }\end{array}$ \\
\hline 189 & M23 & I don't] \\
\hline 190 & W22 & $\begin{array}{l}\text { ]what gives you the right to knock somebody's self-esteem to destroy somebody (.) emotionally } \\
\text { for the sake of your prejudice } \uparrow \text { if you went up to a coloured person and said (.) I'm not going to } \\
\text { give you respect because you're black (.) short or have big feet (.) you are humiliating people (.) } \\
\text { you'd be breaking the law in some cases but because you're big (.) what gives you the right } \uparrow \\
((\text { applause)) }\end{array}$ \\
\hline 191 & M23 & $\begin{array}{l}\text { it's my opinion (.) the majority of blokes in this country agree (.) ninety percent of blokes in this } \\
\text { country like slim birds (.) it's as simple as that (.) and it's their opinion as well] }\end{array}$ \\
\hline 192 & W22 & ]not necessarily (.) $\mathrm{mr}$ perfect $=$ \\
\hline 193 & M23 & $=\mathrm{it}$ is \\
\hline 194 & W22 & don't you think it's wrong $\uparrow$ \\
\hline 195 & M23 & no (.) it's just reality \\
\hline 196 & W22 & $\begin{array}{l}\text { no (.) it isn't (.) I think you are the most ignorant creature I've ever met (.) you should be on a } \\
\text { veranda playing a banjo ((applause)) }\end{array}$ \\
\hline 197 & K & $\begin{array}{l}\text { calm down (.) calm down } \\
{[\ldots]}\end{array}$ \\
\hline 320 & M23 & $\begin{array}{l}\text { I'd like to ask all these people that are so proud of themselves (.) why are you on a diet } \uparrow(.) \text { Many } \\
\text { people don't dare to say this but (.) let's be sincere (.) at the end of the day (.) it seems to me (.) you } \\
\text { hate yourself and you'd like to be slim and beautiful }\end{array}$ \\
\hline 321 & W22 & you're wrong \\
\hline 322 & M23 & oh well (.) I don't think so (.) you are a bunch of liars (.) you'd like to say the truth but] \\
\hline 323 & W22 & $\begin{array}{l}\text { ]because we're fat and we would like to be models (.) I prefer being as I am than being like you (.) } \\
\text { you don't have the right to look down upon us (.) you're worthless }\end{array}$ \\
\hline 324 & M23 & $\begin{array}{l}\text { you're a bunch of liars (.) definitely (.) you're fat (.) you're ugly (.) people don't find you attractive } \\
\text { and that's why you're on a diet (.) admit you don't like being fat }\end{array}$ \\
\hline 325 & W22 & no $($.$) no (2.3)$ why are you so cruel $\uparrow$ what's wrong with you $\uparrow$ \\
\hline 326 & M23 & $\begin{array}{l}\text { nothing (.) I'm just saying the truth (.) it's a fact (.) people want to be slim (.) stop fooling } \\
\text { yourself= }\end{array}$ \\
\hline 327 & W22 & $=$ I'm not fooling ]myself \\
\hline 328 & M23 & $\begin{array}{l}\text { Jyes you are (.) I don't care what people think of me (.) unless I know they're right and you admit } \\
\text { it or not (.) you know I'm right (.)I just say what other would like to say but they are ]afraid }\end{array}$ \\
\hline 329 & W22 & $\begin{array}{l}\text { Jas the lady over there said (.) you're the most ignorant creature in this world (.) and listen to me } \\
\text { (.) you will end up alone in life as you deserve }\end{array}$ \\
\hline 330 & M23 & oh yes (.) but I am not fat \\
\hline 331 & W22 & you're a MONSTER \\
\hline 332 & $\mathrm{~K}$ & calm down (.) calm down \\
\hline
\end{tabular}


M23 risks his social identity on television and gives priority to his personal cost. He denies the impositions deriving from the common demands placed upon any individual group member by the ingroup in order to maintain ingroup cohesiveness and uniformity (Hogg and Vaughan, 1995). The persuasive strategy consits of:

(a) Challenging the established social conventions. The main defining quality of the previous strategy is that it represents attempts by M23 as a social being to persuade his opponents by subordinating his personal identity in favour of his social identity. As Tajfel and Turner (1986: 19-20) suggest, this self-presentation strategy "seeks positive distinctiveness for the in-group by redefining or altering the elements of the comparative situation". In the extract, M23 challenges the established social conventions the outgroup represents (turn 320: "I'd like to ask all these people that are so proud of themselves (.) why are you on a diet $\uparrow$; Turn 324: "you're a bunch of liars (.) definitely (.) you're fat (.) you're ugly (.) people don't find you attractive and that's why you're on a diet (.) admit you don't like being fat") and nominates himself the speaker of a bigger group in order to support his argument ("Turn 121: it's my opinion (.) the majority of blokes in this country agree (.) ninety percent of blokes in this country like slim birds (.) it's as simple as that (.) and it's their opinion as well]").

Although Hogg and Vaugham (1995) consider the possibility of having different roles in a particular social group, these roles are determined by an intergroup behaviour "among individuals that is regulated by those individuals' awareness of and identification with different social groups" (Ibid.: 348). Needless to say, these roles can be understood as norms in so far as they describe the appropriate course of action that is applied to the ingroup as a whole. This point of view has an interesting implication in the analysis of this particular persuasive strategy in TV interaction as this stance claims that social behaviour is fundamentally influenced by the social categories to which we belong and power and status relations between those social categories. However, nothing is said about what regulates individual behaviours that seem to be regulated by the need of individuals to satisfy their needs and defend their self face behaviour at any cost. As seen in the extract, M23 constructs contrast between himself and the outgroup categories through talk-in-interaction (Dickerson, 1999). He depicts himself as "I'm different to you and that makes me better than you are".

(b) Quest for individual autonomy. However, M23 is not interested in representing a particular group and M23 goes on to contrast himself with his own group as a means of asserting his individual autonomy (Turn 320: "Many people don't dare to say this but (.) let's be sincere (.) at the end of the day (.) it seems to me (.) you hate yourself and you'd like to be slim and beautiful") and depicting himself as unique (Turn 328: "I don't care what people think of me (.) unless I know they're right and you admit it or not (.) you know I'm right (.)I just say what other would like to say but they are ]afraid"). M23 perceives that he wants different things and imposes competitive motives on his opponents while ignoring common social conventions. 


\section{Conclusions}

The relation between persuasion and dissuasion is non-trivial. In this paper, an analysis of the distinct persuasive strategies employed in TV conflict talk makes it possible to argue that, contrary to the belief of Social Identity Theory and Self-Categorisation Theory, the act of drawing a contrast between oneself and the others, and of negotiating information, is far from being accomplished in a mechanistic fashion but occurs in a way which demonstrates intricate orientation to the particulars of the talk context.

Persuasion is therefore the overt business of constructing identity and positioning oneself in interaction. The analysis of the data has revealed that persuasive discourse and identity message behaviour in talk show conflict talk can be usefully classified into three types of face work act: a) Defending self-face behaviours. This persuasive strategy is based on justifying socially inacceptable social actions such as being unfaithful, leaving your partner behind, bullying another, etc. The justification centres around describing a socially (in)acceptable emotional behaviour as passive reaction whereas the opponent conceptualises the same event as controllable action; b) Attacking and restoring self-face behaviours. This persuasive strategy is as common as effective in talk show verbal duels. Those guests that are responsible for reprehensible actions attempt to introduce some new comparison dimension while playing with the past/present dichotomy. The effectiveness of the strategy lies in the fact that there is an immense social pressure that guests use to create more and more connections with the studio audience. The opponent can feel the social pressure and eventually conforms to what the studio audience considers socially acceptable. In this context, this strategy can be regarded as a conflict resolution strategy in so far as it uses persuasion as a means of achieving wide consensus; and c) Defending selfface behaviours and attacking other's face behaviours. This persuasive strategy shows shows how the negotiation of meaning provides a central force for the constitution of social relations. This contentious, coercive behaviour may not fulfil the needs of the individual efficiently (Donahue, 2001). In a talk show interaction, parties are dependent on one another in so far as they can mutually control one another's behaviour by relying on simple socially acceptable behaviours (e.g. drinking, leaving your wife behind, or abandoning a child do not live up to socially acceptable standards). All in all, this study has suggested that conflict talk is not only used as an ideological vehicle for attitude change, but that it also exerts a powerful force of social cohesion on the audience.

\section{Notes}

1. For transcription conventions used in the extracts, see Appendix.

\section{References}

Alston, W. P. (2000): Illocutionary Acts and Sentence Meaning. Ithaca: Cornell University Press. Antaki, C. (1994): Explaining and Arguing: The Social Organisation of Accounts. London: Sage Publications. 
Arbib, M.A. and Fellous, J.M. (2004): "Emotions: from brain to robot". Trends in Cognitive Sciences 8: 554-561.

Augoustinos, M. and Walker, I. (1995): Social Cognition. An Integrated Introduction. London: Sage publications.

Austin, J.L. (1962): How to do things with words. Oxford: Clarendon Press.

Barker, C. and Galasinski, D. (2001): Cultural Studies and Discourse Analysis. A Dialogue on Language and Identity. London: Sage publications.

Bodenhausen, G. V., and Lichenstein, M. (1987): "Social stereotypes and information-processing strategies: The impact of task complexity". Journal of Personality and Social Psychology 52: 871-880.

Briggs, C. L. (1996): “Introduction”. In C. L. Briggs, ed., Disorderly Discourse. Narrative, Conflict and Inequality. Oxford: Oxford University Press, 3-40.

Brown, P. and Levinson, S. (1987): Politeness. Cambridge: Cambridge University Press.

Charteris-Black, J. (2004): "Why 'an angel rides in the whirlwind and directs the storm': a corpusbased comparative study of metaphor in British and American political discourse". Language and Computers 49 (1): 133-150.

Cotterill, J. (2003): Language in Court: Power and Persuasion in the O.J. Simpson Trial. Palgrave: Basingstoke.

Dickerson, P. (1999): Activity orientation in the talk of politicians, news, journalists and audiences. Unpublished Ph. D. University College London.

. (2001): "Disputing with care: analyzing interviewees' treatment of interviewers' prior turns in televised political interviews". Discourse Studies 3: 203-222.

Donahue, W. (2001): "Resolving Relational Paradox: The language of conflict in relationships". In W.F. Eadie and P.E. Nelson, eds., The Language of Conflict and Resolution. London: Sage publications, 21-46.

Edwards, D. (2000): "Extreme case formulations: softeners, investment, and doing nonliteral". Research on Language and Social Interaction 33(4): 347-373.

Edwards, D. and Potter, J. (1992): Discursive Psychology. London: Sage Publications.

Ellemers, N. (1993): "Influence of socio-structural variables on identity enhancement strategies". Eur. Rev. Social Psychology 4:27-57.

Ellis, A. (2001): Overcoming Destructive Beliefs, Feelings, and Behaviors: New Directions for Rational Emotive Behavior Therapy. New York: Prometheus Books.

Foucault, M. (1972): The Archeology of Knowledge. New York: Pantheon.

García Gómez, A. (2000): "Discourse, politeness and gender roles: an exploratory investigation into British and Spanish Talk show verbal conflict". Estudios Ingleses de la Universidad Complutense 8: $97-125$.

. (2007): Habla conflictiva como acción social. Discurso y Cognición. Oviedo: Septem Ediciones.

. (2009): La conversacionalización del discurso mediático en la televisión británica. Ideología, poder y cambio social. Oviedo: Septem Ediciones.

Gavruseva, L. (1995): "Positioning and framing: constructing interactional asymmetry in employeremployee discourse". Discourse Processes 20: 325-345.

Gregori-Signes, C. (2000): "The tabloid Talkshow a quasi-conversational type of facte-to-face interaction”. Pragmatics 10 (2): 195-213.

. (2001): "Opening Phase in American Tabloid Talkshows". In I. de la Cruz, C. Santamaria, C. Tejedor and C. Valero, eds., La lingüística aplicada a finales del siglo XX. Ensayos y propuestas. Servicio de Publicaciones de la Universidad de Alcalá, 555-562. 
Grimshaw, A. D. (ed.) (1990): Conflict Talk: Sociolinguistic investigations of arguments in conversations. Cambridge: Cambridge University Press, 67-84.

Hammer, M. R. (2001): "Conflict negotiation under crisis conditions". In W. F. Eadie and P. E. Nelson, eds., The language of conflict resolution. Thousand Oaks, CA: Sage, 57-80.

Harris, S. (2001): "Being politically impolite: extending politeness theory to adversarial political discourse". Discourse and Society 12: 451-472.

Hogg, M. A. and Vaughn, G. M. (1998): Social Psychology. London: Prentice Hall.

Hutchby, I. (1996a): Confrontation Talk - Arguments, asymmetries, and Power on Talk Radio. Mahwah, NJ: Lawrence Erlbaum Associates.

. (1996b): "Power in discourse: the case of arguments on a British talk radio show", Discourse and Society 7 (4): 481-497.

Illie, C. (1999): "Question-response argumentation in talk shows". Journal of Pragmatics 31: 975-999.

. (2001): "Semi-institutional discourse: The case of talk shows". Journal of Pragmatics 33 (2): 209- 254.

Hutchby, I. (1999): "Frame attunement and footing in the organisation of talk radio openings". Journal of Socioloinguistics 3 (1): 41-63.

Joseph, J. E. (2004): Language and Identity. Palgrave: Basingstoke.

Jost, J. T. (1995): "Toward a Wittgensteinian Social Psychology of Human Development". Theory and Psychology 5 (1): 5-25.

Koester, A. (2006): Investigating Workplace Discourse. London: Routledge.

Lorenzo-Dus, N. (2005): “A rapport and impression management approach to public figures' perfomance of talk". Journal of Pragmatics 37 (5): 611 - 631.

Myers, G. (2001): 'I'm Out of It; You Guys Argue': Making an Issue of It on The Jerry Springer

Show". Television Talk Shows. Discourse, Performance, Spectacle. Ed. A. Tolson. Mahwah, N.J.: Erlbaum. 173-192.

O'Keeffe, A. (2006): Investigating Media Discourse. London: Routledge

Pérez de Ayala, S. (2001): "FTAs and Erskine May: conflicting needs? - politeness in question time". Journal of Pragmatics 33: 143-169.

Potter, J. (1997): “Discourse analysis as a way of analysing naturally occurring talk". In D. Silverman, ed., Qualitative Research: Theory, Method and Practice. London: Sage Publications, 144-160.

Potter, J. and Wetherell, M. (1987): Discourse and Social Psychology. London: Sage

Putnan, S. (2001): Conflict in language. London: Routledge

Rama Martínez, E. (2003): "Accomplishing closings in talk show interviews: a comparison with news interviews". Discourse Studies 5: $283-302$.

Rogan R. G., and Hammer, M. R. (1994): "Crisis negotiations: A preliminary investigation of facework in naturalistic conflicts". Journal of Applied Communication Research 22: 216-231.

Sacks, H. (1992): Lectures on Conversation. Oxford: Blackwell.

Schegloff, E. A. (1995): "Discourse as an International achievement III: The Omnirelevance of Action". Research on Language and Social Interaction 28: 185 - 211.

Shotter, J. (1993): Conversational Realities. Constructing Life Through Language. London: Sage Publications.

Tajfel, H. and Turner, J. C. (1979): “An integrative theory of intergroup conflict”. In W.G. Austin and S. Worchel. Monterey, eds., The Social Psychology of Interpersonal Relations. C. A.: Brooks / Cole, 33-47.

Thornborrow, J. (2001a): “Authenticating talk: building public identities in audience participation broadcasting”. Discourse Studies 3 (4): 459 - 479. 
. (2001b): “Authenticity, talk and mediated experience". Discourse Studies 3 (4): 391-411.

van Eemeren, F. H. and Grootendorst, R. (1984): Speech Acts in Argumentative Discussions: A Theoretical Model for the Analysis of Discussions Directed towards Solving Conflicts of Opinion. Dordrecht, Foris/Mouton de Gruyter.

van Eemeren, F. H. and Grootendorst, R. (1992): Argumentation, Communication, and Fallacies: A Pragma-Dialectical Perspective. Hillsdale (NJ), Lawrence Erlbaum.

Vuchinich, S. (2003a): "Social Problem Solving Training with Families". In E. C. Chang, T. J. D'Zurilla and L. J. Sanna, eds., Social Problem Solving: Theory, Research and Training. American Psychological Association: Washington, DC, 34-43.

. (2003b): "Family problem solving". In J. Ponzetti, ed., The International Encyclopedia of Marriage and Family Relationships. Macmillan Reference USA: NY, 57-74.

Vuchinich, S., Ozretich, R., Pratt, C. and Kneedler, B. (2002): "Problem-Solving Communication in Foster Families and Birthfamilies". Child Welfare 81, 571-595.

Willock, R. K. (1994): "Easy access to sloppy truths: The '92 presidential media campaign”. In S. A. Smith, ed., Bill Clinton on stump, state, and stage: The Rhetorical road to the White House. Fayetteville, AR: University of Arkansas Press, 292-314.

Wood, H. (2001): "No, YOU Rioted!': The Pursuit of Conflict in the Management of "Lay" and "Expert" Discourses on Kilroy". In A. Tolson, ed., Television Talk Shows. Discourse, Performance, Spectacle. Mahwah, N.J.: Erlbaum, 65-88.

\section{Appendix: Transcription conventions}

The following conventions were developed by Gail Jefferson.

\begin{tabular}{|c|c|}
\hline [] & $\begin{array}{l}\text { Square brackets mark the start and end of overlapping speech. Position them in } \\
\text { alignment where the overlap occurs }\end{array}$ \\
\hline$\uparrow \downarrow$ & $\begin{array}{l}\text { Vertical arrows precede marked pitch movement, over and above normal rhythms } \\
\text { of speech. They are for marked, hearably significant shifts - and even then, the } \\
\text { other symbols (full stops, commas, question marks) mop up most of that. Like } \\
\text { with all these symbols, the aim is to capture interactionally significant features, } \\
\text { hearable as such to an ordinary listener - especially deviations from a common } \\
\text { sense notion of 'neutral', which admittedly has not been well defined }\end{array}$ \\
\hline CAPITALS & $\begin{array}{l}\text { Capitals mark speech that is obviously louder than surrounding speech (often } \\
\text { occurs when speakers are hearably competing for the floor, raised volume rather } \\
\text { than doing contrastive emphasis) }\end{array}$ \\
\hline$(0.4)$ & $\begin{array}{l}\text { Numbers in round brackets measure pauses in seconds (in this case, } 4 \text { tenths of a } \\
\text { second). Place on new line if not assigned to a speaker }\end{array}$ \\
\hline (.) & A micropause, hearable but too short to measure \\
\hline$(($ text $))$ & Additional comments from the transcriber, e.g. context or intonation \\
\hline
\end{tabular}




\begin{tabular}{|l|l|}
\hline she wa::nted & $\begin{array}{l}\text { Colons show degrees of elongation of the prior sound; the more colons, the more } \\
\text { elongation }\end{array}$ \\
\hline \hline Solid. $=$ & 'Equals' signs mark the immediate 'latching' of \\
\hline =We had & $\begin{array}{l}\text { successive talk, whether of one or more speakers, with no interval. Also used as } \\
\text { below (lines 3-5), where an unbroken turn has been split between two lines to } \\
\text { accommodate another speaker on the transcript page }\end{array}$ \\
\hline
\end{tabular}

